\title{
Inhibition of carbon steel corrosion by imidazoline in carbon dioxide saturated oilfield brine solution
}

\section{Korrosionshemmung von Kohlenstoffstahl durch Imidazolin in Kohlendioxid gesättigter Ölfeld-Salzwasserlösung}

\author{
D. Doležal ${ }^{1}$, V. Alar², T. Borko
}

This work focuses on the testing of imidazoline based corrosion inhibitor and the inhibition of carbon steel corrosion caused by carbon dioxide saturated oilfield brine solution. Electrochemical impedance spectroscopy, linear polarization, anodic and cathodic polarization (Tafel extrapolation method) measurements were carried out.

In order to investigate imidazoline based corrosion inhibitor efficiency, carbon dioxide saturated oilfield brine solution without inhibitor and solution with added different concentrations of imidazoline based corrosion inhibitor were tested. Those results were compared. Influence of testing solution temperature and stirring of testing solution on the corrosion inhibitor efficiency were investigated.

On the basis of obtained results it can be concluded that optimal concentration of imidazoline based corrosion inhibitor is $50 \mathrm{ppm}$ for the successful and effective corrosion protection of pipelines made of carbon steel under test conditions similar to typical oilfield conditions $\left(35^{\circ} \mathrm{C}\right.$, atmospheric pressure, stirring rate $400 \mathrm{~min}^{-1}$ ).

Keywords: carbon steel / corrosion inhibitor efficiency / imidazoline / oilfield brine

Diese Arbeit befasst sich mit der Prüfung von auf Imidazolin basiertem Korrosionsinhibitor und dessen Hemmung auf die Korrosion von Kohlenstoffstahl verursacht durch Ölfeld-Salzwasserlösung, die mit Kohlendioxid gesättigt ist. Es wurden Messungen zur elektrochemischen Impedanzspektroskopie, die Methode der linearen Polarisation sowie anodische und kathodische Polarisationsmessungen (Tafel Extrapolationsmethode) durchgeführt.

Um die Effizienz des auf Imidazolin basierten Korrosionsinhibitors zu untersuchen, wurde die mit Kohlendioxid gesättigte Ölfeld-Salzwasserlösung ohne Inhibitor und die Lösung mit unterschiedlichen Konzentrationen des Inhibitors getestet und miteinander verglichen. Auch der Einfluss der geprüften Lösungstemperatur und die Bewegung der Prüflösung auf die Wirkung des Korrosionsinhibitors ist untersucht worden.

Auf Grundlage der erzielten Ergebnisse kann geschlossen werden, dass die optimale Konzentration für einen auf Imidazolin basierten Korrosionsinhibitor 50 ppm beträgt, um einen erfolgreichen und effektiven Korrosionsschutz von Pipelines aus Kohlenstoffstahl unter ähnlichen Testbedingungen wie den ölfeldbedingungen $\left(35^{\circ} \mathrm{C}\right.$, Atmosphärendruck, Rührgeschwindigkeit 400 $\min ^{-1}$ ) zu erhalten.

Schlüsselwörter: Kohlenstoffstahl / Korrosionsinhibitor / Imidazolin / Ölfeld-Salzwasser

\section{Introduction}

Damage due to corrosion is a very serious problem in the oil industry [1]. Pipelines and many other structures used in the production of oil and gas are usually made of carbon steel [2-5]. Car-

\footnotetext{
${ }^{1}$ INA-Oil Industry, Zagreb, Croatia

${ }^{2}$ University of Zagreb, Faculty of Mechanical Engineering and Naval Architecture, Zagreb, Croatia
}

Correspondence author Dubravka Doležal, INA-Oil Industry, Lovinciceva b.b., 10002 Zagreb, Croatia

E-mail: dubravka.dolezal@ina.hr bon and low alloy steels are economical construction material in oil technology, but they are susceptible to corrosion processes [6].

Fluids which flow through oil and gas pipelines are mostly multiphase and contain oil, aqueous phase (salt water) and gas phase [7]. Water and oil can make an emulsion that will not be corrosive if water is emulsified in hydrocarbons [8]. However, if water is present as a free water, very corrosive conditions could occur $[8,9]$.

Pipelines filled with oilfield brine may be exposed to internal corrosion. Therefore, corrosion inhibitors and/or coatings are used in order to protect pipelines $[1,3,8]$. One of the modern and very important methods of corrosion prevention is the use of corrosion inhibitors and many plants and systems are dependent on 
their successful application [2]. Corrosion inhibitors are widely used in the control of carbon steel corrosion in the oil technology on the basis of its easy application, availability and economical cost [10]. Corrosion inhibitors are the cheapest and most flexible agent in the control of internal corrosion of long pipelines in the oilfields $[6,11]$. Tests of forty corrosion inhibitors added into oilfield brine have been described [12]. Useful properties of corrosion inhibitors in oilfield have been described [13].

Imidazoline based corrosion inhibitors have been well used for the protection of oilfield pipelines for many years [14-18]. Extensive use of imidazoline based corrosion inhibitors in the oil technology is based on their proven strong adsorption on the metal surface; metal surface covered with imidazoline film constitutes a barrier to water and to the other corrosive agents [15]. Certain imidazoline based corrosion inhibitors are environmentally friendly [19]. After the corrosion inhibitor is added into oilfield brine which flows through pipelines, its residual concentration should be monitored in order to ensure effective protection of the pipelines $[2,15]$. Methodology for monitoring residual concentration of imidazoline based corrosion inhibitors in oilfield brine has been described [20,21].

Testing of imidazoline based corrosion inhibitors in the protection of carbon steel immersed in the carbon dioxide saturated solution with chlorides (or oilfield brine), performed by electrochemical methods, have been described in many papers [22-28]. In this paper electrochemical impedance spectroscopy (EIS) measurements, linear polarization measurements and anodic and cathodic polarization measurements (Tafel extrapolation method) were done in order to test imidazoline based corrosion inhibitor for the protection of carbon steel in carbon dioxide saturated oilfield brine solution. Tests were performed without corrosion inhibitor and with addition of different concentrations of imidazoline based corrosion inhibitor. Testing conditions were similar to the conditions in the oilfield and influence of testing solution temperature and stirring of testing solution were investigated as well.

\section{Experiment}

\subsection{Instrumentation and materials}

Tests were conducted using a three-electrode arrangement: carbon steel AISI 1018 as working electrode; standard saturated calomel electrode as a reference electrode (it was in contact with the working electrode by Luggin capillaries) and two graphite electrodes as counter electrodes. All tests were performed using a 1 liter specially designed glass vessel with double layer (electrochemical cell). Temperature of testing solution (oilfield brine) was maintained at $35^{\circ} \mathrm{C}$ or $70^{\circ} \mathrm{C}$, it was controlled by isothermal water bath ED-5 (Julabo, Germany, Serial Number 10121499). Testing solution (electrolyte) was saturated with carbon dioxide. The exact formulation of imidazoline based corrosion inhibitor, which was added into testing solution, has been highly protected by inhibitor manufacturer. All measurements were carried out using a potentiostat Parstat 2633 (Princenton Applied Research, USA, Serial Number 07213387), which was controlled using software (ZSimpWin 3.21 and PowerSuite ZView 2). Magnetic stirrer RCT Basic IKAMAG (IKA, Germany, Serial Number 00.089906)
Table 1. Results obtained by EIS measurements in the carbon dioxide saturated oilfield brine solution without corrosion inhibitor

Tabelle 1. Ergebnisse der EIS - Messungen in der Kohlendioxid gesättigten Ölfeld Salzwasserlösung ohne Korrosionsinhibitor

\begin{tabular}{lccc}
\hline $\begin{array}{l}\text { Metal immersion } \\
\text { period, hour }\end{array}$ & 3 & 5 & 22 \\
\hline$R_{\mathrm{el}}$, Ohm & 7,27 & 6,07 & 8,33 \\
$R_{\mathrm{pr}}$ Ohm & 48,2 & 48,3 & 114 \\
$C_{\mathrm{dl}}, \mathrm{F}$ & 319,1 & 408,0 & 233,4 \\
\hline
\end{tabular}

was used for the stirring of electrolyte. The surface of the coupon (carbon steel AISI 1018) was polished by an automatic polishing machine Rotopol-21 (Struers, Denmark, Serial Number 5150028) equipped with 800 grit paper.

\subsection{Testing Procedure}

Electrochemical studies were carried out in accordance with the requirements of the ASTM standards G3 [29], G5 [30], G59 [31], G102 [32], G106 [33] and G193 [34]. Electrochemical cell was equipped with all required equipment and filled with the testing solution (oilfield brine). Working electrode was inserted later. The oilfield brine $(0.81)$ was put into the electrochemical cell and appropriate concentration of imidazoline based corrosion inhibitor was added if the testing was performed with the addition of corrosion inhibitor. Testing solution was saturated with carbon dioxide for the period of 40 minutes. After that, the sample of carbon steel AISI 1018 (coupon) was polished and put into the working electrode holder and inserted into the electrochemical cell. Its surface was $1 \mathrm{~cm}^{2}$. If it was used, magnetic stirrer was set at stirring rate of $400 \mathrm{~min}^{-1}$. After achieving stable testing condition electrochemical impedance spectroscopy measurements and linear polarization measurements were carried out. Anodic and cathodic polarization measurements (Tafel extrapolation method) with the rate of change of the potential of $5 \mathrm{mVs}^{-1}$ followed.

\section{Results and discussion}

The Table 1 presents results of EIS measurements and period of time from metal immersion into electrolyte. The temperature of testing solution was $35^{\circ} \mathrm{C}$, pressure was atmospheric and solution was stirred $\left(400 \mathrm{~min}^{-1}\right)$. The results allow conclusions to be made about the time sequence of changes on the metal surface and its influence on the corrosion rate. A layer of corrosion products was created after 22 hours on the metal surface. The corrosion products layer complicated the further transport of metal ions from the surface. It was registered by the higher resistance values.

The Table 2 gives results of linear polarization measurements performed without corrosion inhibitor. These results show that corrosion rate decreased in the first 5 hours (from $1.80 \mathrm{~mm} /$ year to $0.51 \mathrm{~mm} /$ year) and after that corrosion rate increased. Corrosion rate measured after 22 hours of carbon steel coupon AISI 1018 immersion in the testing solution was a three times lower $(0.67 \mathrm{~mm} /$ year $)$ than the initial corrosion rate $(1.80 \mathrm{~mm} /$ year $)$. 
Table 2. Results obtained by linear polarization measurements in the carbon dioxide saturated oilfield brine solution without corrosion inhibitor

Tabelle 2. Gewonnene Ergebnisse durch lineare Polarisationsmessungen in der Kohlendioxid gesättigten Ölfeld Salzwasserlösung ohne Korrosionsinhibitor

\begin{tabular}{|c|c|c|c|c|c|c|c|c|}
\hline $\begin{array}{l}\text { Metal immersion period, } \\
\text { hour }\end{array}$ & 0,5 & 1 & 2 & 3 & 3,5 & 4 & 5 & 22 \\
\hline$E_{\text {corr, }} \mathrm{mV}$ us. SCE & -713 & -712 & -712 & -711 & -712 & -713 & -713 & -720 \\
\hline$U_{\text {corr, }} \mathrm{mm}_{\text {year }}{ }^{-1}$ & 1,80 & 1,04 & 0,74 & 0,61 & 0,58 & 0,54 & 0,51 & 0,67 \\
\hline
\end{tabular}

Table 3. Results obtained by Tafel extrapolation method in the carbon dioxide saturated oilfield brine solution with and without corrosion inhibitor

Tabelle 3. Gewonnene Ergebnisse der Tafel Extrapolationsmethode in der Kohlendioxid gesättigten Ölfeld Salzwasserlösung mit und ohne Korrosionsinhibitor

\begin{tabular}{llllll}
\hline $\begin{array}{l}\text { Corrosion inhibitor } \\
\text { concentration, ppm }\end{array}$ & 0 & 20 & 50 & 100 & 200 \\
\hline$E_{\text {corr, }} \mathrm{mV}$ us. SCE & -702 & -693 & -698 & -674 & -655 \\
$U_{\text {corr, }} \mathrm{Vmear}^{-1}$ & 0,51 & 0,33 & 0,13 & 0,20 & 0,17 \\
$-b_{\mathrm{a}}, \mathrm{Vec}^{-1}$ & 44 & 63 & 78 & 89 & 113 \\
$-b_{\mathrm{c}}, \mathrm{V} \mathrm{dec}^{-1}$ & 316 & 277 & 265 & 460 & 440 \\
\hline
\end{tabular}

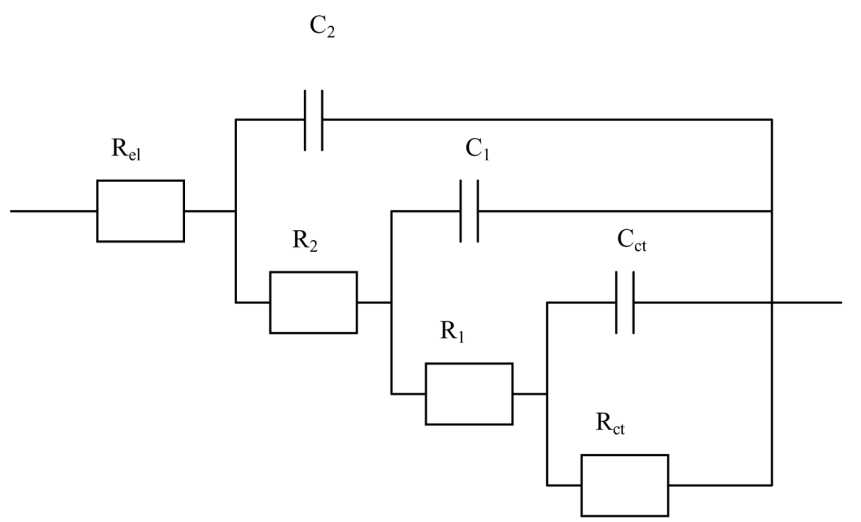

Fig. 1. The equivalent electrical circuit for the system with addition of imidazoline based corrosion inhibitor

Bild 1. Die äquivalente elektrische Schaltung für das System unter Zusatz von Imidazolin basierten Korrosionsinhibitor

Application of Tafel extrapolation method for the examination of the system without corrosion inhibitor, performed after 22 hours from metal immersion into testing solution, gave the corrosion rate of $0.51 \mathrm{~mm} /$ year, Table 3 . This corrosion rate is very similar to the corrosion rate obtained by linear polarization measurement, performed after 22 hours from metal immersion into testing solution; it was $0.67 \mathrm{~mm} /$ year, Table 2 .

Two hours after metal immersion into testing solution the chosen concentration of imidazoline based corrosion inhibitor was added into testing solution in order to investigate influence of inhibitor concentration on film resistance and on the corrosion rate. The following concentrations of corrosion inhibitors were studied: $20 \mathrm{ppm}, 50 \mathrm{ppm}, 100 \mathrm{ppm}$ and $200 \mathrm{ppm}$. The temperature of testing solution was $35^{\circ} \mathrm{C}$, pressure was atmospheric and solution was stirred $\left(400 \mathrm{~min}^{-1}\right)$. The Table 3 presents the results obtained by Tafel extrapolation method in the carbon dioxide saturated oilfield brine solution without and with the addition of imidazoline based corrosion inhibitor. Tested metal was immersed into testing solution for 22 hours at all tested concentrations.

The equivalent electrical circuit, shown at the Figure 1, was used for the approximation of impedance data in the system with added imidazoline based corrosion inhibitor. The equivalent electrical circuit consists of electrolyte resistance $R_{\mathrm{el}}$, resistance of the first inhibitor layer $R_{1}$, resistance of the second inhibitor layer $R_{2}$, resistance of double layer $R_{\mathrm{ct}}$, capacity of the first inhibitor layer $C_{1}$, capacity of the second inhibitor layer $C_{2}$ and capacity of double layer $C_{\mathrm{ct}}$.

The results for the EIS measurements and linear polarization measurements conducted in the system with 20, 50, 100 and 200 ppm of corrosion inhibitor are presented in the Tables 4-7, respectively.

\subsection{Comparison of the obtained results in the testing of carbon steel corrosion in carbon dioxide saturated oilfield brine solution without corrosion inhibitor and with the addition of imidazoline based corrosion inhibitor}

The Figure 2 shows common Nyquist curves for different concentrations of imidazoline based corrosion inhibitor in the studied system. Carbon steel coupon AISI 1018 was immersed for 22 hours and after that Nyquist curves were scanned. Nyquist curves show that resistance toward corrosion process increased until the concentration of $100 \mathrm{ppm}$ was reached. Addition of 200 ppm of corrosion inhibitor resulted in decreased corrosion inhibitor efficiency.

The obtained resistance values of the studied inhibitors vary for every layer. This fact leads to the conclusion about different molec- 
Table 4. The results for the EIS and linear polarization measurements conducted in the system with $20 \mathrm{ppm}$ of imidazoline based corrosion inhibitor

Tabelle 4. Die Ergebnisse der EIS- und linearen Polarisationsmessungen wurden im System mit 20 ppm von Imidazolin basierten Korrosionsinhibitor durchgeführt

\begin{tabular}{llll}
\hline $\begin{array}{l}\text { Metal immersion } \\
\text { period, hour }\end{array}$ & 4,5 & 6 & 22 \\
\hline$R_{\mathrm{el}}, \mathrm{Ohm}$ & 4,57 & 4,40 & 5,84 \\
$R_{1}, \mathrm{Ohm}$ & 163,5 & 200,1 & 234,7 \\
$R_{2}, \mathrm{Ohm}$ & 85,1 & 42,2 & 20,9 \\
$C_{\mathrm{dl}}, \mathrm{F}$ & 128,0 & 239,7 & 429,0 \\
$E_{\text {corr, }} \mathrm{mV}$ us. SCE & -708 & -710 & -709 \\
$U_{\text {corr, }} \mathrm{mm}_{\text {year }}{ }^{-1}$ & 0,49 & 0,49 & 0,34 \\
\hline
\end{tabular}

Table 5. The results for the EIS and linear polarization measurements conducted in the system with $50 \mathrm{ppm}$ of imidazoline based corrosion inhibitor

Tabelle 5. Die Ergebnisse der EIS- und linearen Polarisationsmessungen wurden im System mit 50 ppm von Imidazolin basierten Korrosionsinhibitor durchgeführt

\begin{tabular}{|c|c|c|c|c|}
\hline $\begin{array}{l}\text { Metal immersion } \\
\text { period, hour }\end{array}$ & 2 & 4 & 5,5 & 22 \\
\hline$R_{\mathrm{e}}, \mathrm{Ohm}$ & 3,987 & 4,043 & 4,086 & 8,937 \\
\hline$R_{1}, \mathrm{Ohm}$ & 279,2 & 214,3 & 182,5 & 307,0 \\
\hline$C_{1}, \mathrm{~F}$ & $2,91 \cdot 10^{-5}$ & $4,39 \cdot 10^{-5}$ & $4,65 \cdot 10^{-5}$ & $8,73 \cdot 10^{-5}$ \\
\hline$R_{2}$, Ohm & 27,53 & 15,15 & 15,97 & 33,05 \\
\hline$C_{2}, \mathrm{~F}$ & $8,04 \cdot 10^{-5}$ & $4,94 \cdot 10^{-5}$ & $4,12 \cdot 10^{-5}$ & $2,79 \cdot 10^{-5}$ \\
\hline$R_{\mathrm{dl}}, \mathrm{Ohm}$ & 534,8 & 779,1 & 892,6 & 1050 \\
\hline$C_{\mathrm{dl}}, \mathrm{F}$ & $7,46 \cdot 10^{-5}$ & $5,88 \cdot 10^{-5}$ & $5,77 \cdot 10^{-5}$ & $10 \cdot 10^{-5}$ \\
\hline$E_{\text {corr }}, \mathrm{mV}$ US. SCE & -688 & -691 & -692 & -699 \\
\hline$R, \mathrm{Ohm}$ & 946 & 1171 & 1204 & 1536 \\
\hline$v_{\text {corr }}, \mathrm{mm}$ year $\mathrm{r}^{-1}$ & 0,26 & 0,21 & 0,20 & 0,16 \\
\hline
\end{tabular}

Table 6. The results for the EIS and linear polarization measurements conducted in the system with $100 \mathrm{ppm}$ of imidazoline based corrosion inhibitor

Tabelle 6. Die Ergebnisse der EIS- und linearen Polarisationsmessungen wurden im System mit 100 ppm von Imidazolin basierten Korrosionsinhibitor durchgeführt

\begin{tabular}{|c|c|c|c|}
\hline $\begin{array}{l}\text { Metal immersion } \\
\text { period, hour }\end{array}$ & 4 & 5 & 22 \\
\hline$R_{\mathrm{e},}, \mathrm{Ohm}$ & 5,885 & 5,981 & 2,600 \\
\hline$R_{1}, \mathrm{Ohm}$ & 195,6 & 218,4 & 511,9 \\
\hline$C_{1}, \mathrm{~F}$ & $3,49 \cdot 10^{-5}$ & $3,58 \cdot 10^{-5}$ & $10 \cdot 10^{-5}$ \\
\hline$R_{2}, \mathrm{Ohm}$ & 15,38 & 23,17 & 53,00 \\
\hline$C_{2}, \mathrm{~F}$ & $4,04 \cdot 10^{-5}$ & $3,18 \cdot 10^{-5}$ & $9,25 \cdot 10^{-5}$ \\
\hline$R_{\mathrm{dl}}, \mathrm{Ohm}$ & 903,9 & 982,3 & 998 \\
\hline$C_{\mathrm{d} l}, \mathrm{~F}$ & $4,94 \cdot 10^{-5}$ & $5,40 \cdot 10^{-5}$ & $28 \cdot 10^{-5}$ \\
\hline$E_{\text {corr }}, \mathrm{mV} v \mathrm{~s} . \mathrm{SCE}$ & -677 & -677 & -683 \\
\hline$R, \mathrm{Ohm}$ & 1253 & 1337 & 1682 \\
\hline$v_{\text {corr }} \mathrm{mm}$ year ${ }^{-1}$ & 0,20 & 0,18 & 0,15 \\
\hline
\end{tabular}

ular density or compactness on the metal surface. As the resistance of inhibitor layer is caused by the inability of electrolyte to
Table 7. The results for the EIS and linear polarization measurements conducted in the system with $200 \mathrm{ppm}$ of imidazoline based corrosion inhibitor

Tabelle 7. Die Ergebnisse der EIS- und linearen Polarisationsmessungen wurden im System mit 200 ppm von Imidazolin basierten Korrosionsinhibitor durchgeführt

\begin{tabular}{llll}
\hline $\begin{array}{l}\text { Metal immersion } \\
\text { period, hour }\end{array}$ & 4,5 & 6 & 22 \\
\hline$R_{\mathrm{el}}, \mathrm{Ohm}$ & 5,426 & 5,460 & 4,873 \\
$R_{1}, \mathrm{Ohm}$ & 1130 & 1123 & 646,3 \\
$C_{1}, \mathrm{~F}$ & $12 \cdot 10^{-5}$ & $13 \cdot 10^{-5}$ & $11 \cdot 10^{-5}$ \\
$R_{2}$, Ohm & 85,3 & 110 & 118 \\
$C_{2}, \mathrm{~F}$ & $8,98 \cdot 10^{-5}$ & $7,25 \cdot 10^{-5}$ & 0,00014 \\
$R_{\mathrm{dl}}, \mathrm{Ohm}$ & 788,8 & 812,0 & 300,3 \\
$C_{\mathrm{d}}, \mathrm{F}$ & 0,05448 & 0,05158 & 0,00662 \\
$E_{\text {corr, }} \mathrm{mV}$ us. SCE & -661 & -652 & -653 \\
$R$, Ohm & 1464 & 1485 & 1421 \\
$U_{\text {corr, } \mathrm{mm} \text { year }}{ }^{-1}$ & 0,17 & 0,16 & 0,17 \\
\hline
\end{tabular}

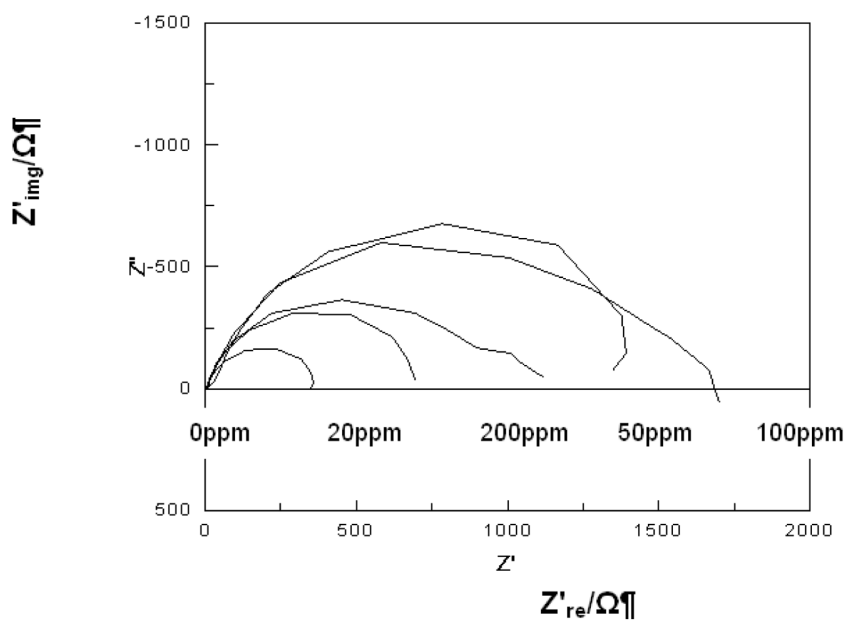

Fig. 2. Common Nyquist curves for different concentrations of imidazoline based corrosion inhibitor in the studied system, after 22 hours of carbon steel coupon AISI 1018 immersion in the testing solution

Bild 2. Gemeinsame Nyquist - Kurven für verschiedene Konzentrationen von Imidazolin basierten Korrosionsinhibitor im untersuchten System, nach 22 stündiger Eintauchung von Kohlenstoffstahl Talon AISI 1018 in der Testlösung

penetrate into inhibitor layer, this value is considered to be associated with resistance to its density, compaction and porosity.

EIS measurements results for different concentrations of imidazoline based corrosion inhibitor, after 22 hours of carbon steel coupon AISI 1018 immersion in the testing solution, are presented in the Table 8. The Figure 3 shows that increase of the inhibitor concentration above $50 \mathrm{ppm}$ has no influence on the increase of inhibitor effectiveness.

Values for corrosion rates obtained by Tafel extrapolation method (after 22 hours of carbon steel coupon AISI 1018 immersion in the testing solution) in the system without corrosion inhibitor and in the system with the addition of different imidazoline based corrosion inhibitor concentrations are presented in the Table 3. 


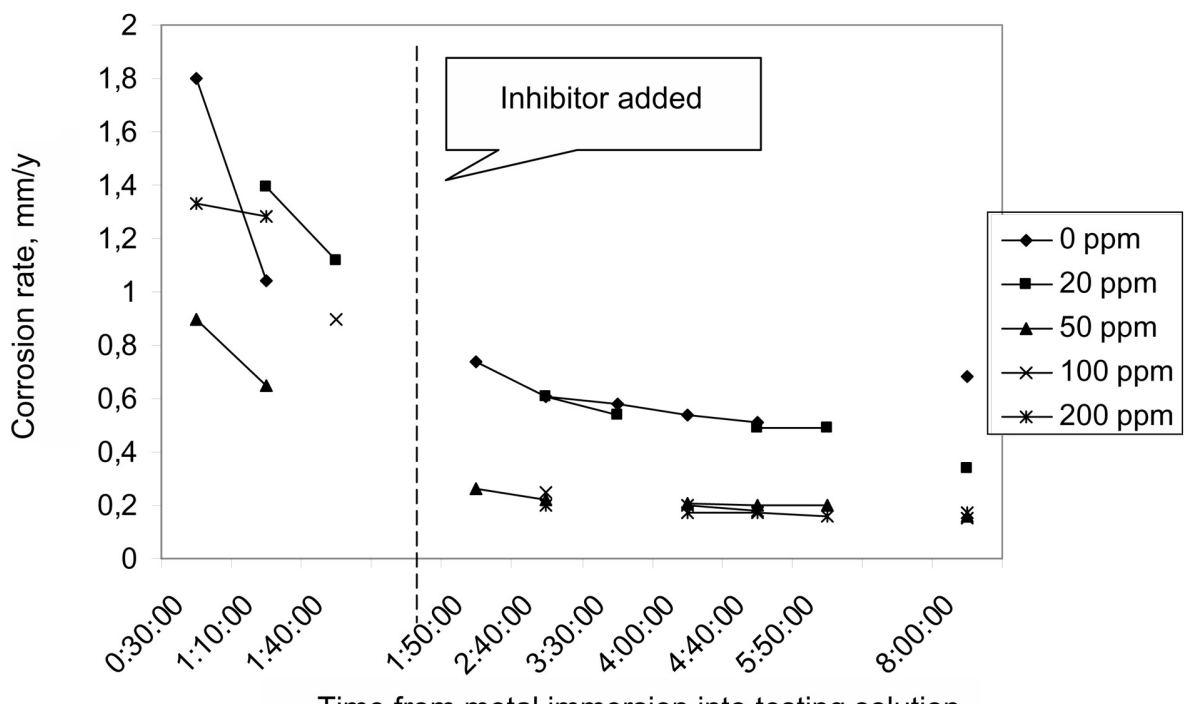

Time from metal immersion into testing solution

Fig. 3. Change of corrosion rate in different time periods and for different corrosion inhibitor concentrations (obtained by linear polarization measurements)

Bild 3. Änderung der Korrosionsrate in verschiedenen Zeiträumen und für unterschiedliche Korrosionsinhibitor Konzentrationen (erhalten durch lineare Polarisationsmessungen)

Table 8. EIS measurements results for different concentrations of imidazoline based corrosion inhibitor, after 22 hours of carbon steel coupon AISI 1018 immersion in the testing solution

Tabelle 8. Ergebnisse der EIS - Messungen verschiedener Konzentrationen von Imidazolin basierten Korrosionsinhibitor, nach 22 stündiger Eintauchung von Kohlenstoffstahl Talon AISI 1018 in der Testlösung

\begin{tabular}{llllll}
\hline $\begin{array}{l}\text { Corrosion } \\
\text { inhibitor con- } \\
\text { centration, ppm }\end{array}$ & 0 & 20 & 50 & 100 & 200 \\
\hline$R_{\mathrm{el}}$, Ohm & 8,33 & 5,84 & 8,94 & 2,60 & 4,87 \\
$R_{\mathrm{pr}}$, Ohm & 114 & - & - & - & - \\
$R_{1}$, Ohm & - & 234,7 & 307,0 & 511,9 & 646,3 \\
$R_{2}$, Ohm & - & 20,9 & 33,1 & 53,0 & 118 \\
$R_{\mathrm{dl}}$, Ohm & 233 & 429 & 1050 & 998 & 300 \\
\hline
\end{tabular}

\subsection{Influence of solution temperature on the imidazoline based corrosion inhibitor efficiency}

Studies of solution temperature influence on carbon dioxide corrosion were conducted under the same conditions as all previously described studies. Only the temperature of testing solution was changed. In previous studies temperature was $35^{\circ} \mathrm{C}$, and in this study the temperature was $70^{\circ} \mathrm{C}$. The results of EIS measurements without corrosion inhibitor after 24 hours immersion of carbon steel coupon AISI 1018 in the testing solution are presented in the Table 9. Comparison of results obtained by linear polarization methods in the carbon steel - oilfield brine system without and with addition of $50 \mathrm{ppm}$ of imidazoline based corrosion inhibitor, tested at $35^{\circ} \mathrm{C}$ and $70^{\circ} \mathrm{C}$, is presented in the Table 10. The corrosion inhibitor efficiency results show that the protection level is higher at lower temperature $\left(35^{\circ} \mathrm{C}\right)$ for the same concentration (50 ppm).
Table 9. Comparison of EIS measurements results for the carbon steel - oilfield brine system without corrosion inhibitor - tested at $35^{\circ} \mathrm{C}$ and $70^{\circ} \mathrm{C}$

Tabelle

9. Vergleich der EIS - Messungsergebnisse für Kohlenstoffstahl Ölfeld Salzwassersystem ohne Korrosionsinhibitor - getestet bei $35^{\circ} \mathrm{C}$ und $70^{\circ} \mathrm{C}$

\begin{tabular}{lll}
\hline Temperature, ${ }^{\circ} \mathrm{C}$ & 35 & 70 \\
\hline$R_{\mathrm{el}}$, Ohm & 8,33 & 3,09 \\
$R_{\mathrm{pr}}$, Ohm & 114,0 & 112,9 \\
$C_{\mathrm{pr}}, \mathrm{F}$ & 0,00043 & 0,00104 \\
$R_{\mathrm{dl}}$, Ohm & 233,4 & 123,3 \\
$C_{\mathrm{dl}}, \mathrm{F}$ & 0,00029 & 0,00417 \\
\hline
\end{tabular}

Table 10. Comparison of results obtained by linear polarization measurements in the carbon steel - oilfield brine system without and with addition of $50 \mathrm{ppm}$ of imidazoline based corrosion inhibitor, tested at $35^{\circ} \mathrm{C}$ and $70^{\circ} \mathrm{C}$

Tabelle 10. Vergleich der gewonnen Ergebnisse durch die lineare Polarisationsmessungen in Kohlenstoffstahl - Ölfeld Salzwasser System ohne und mit Zusatz von 50 ppm Imidazolin basierten Korrosionsinhibitor - getestet bei $35^{\circ} \mathrm{C}$ und $70^{\circ} \mathrm{C}$

\begin{tabular}{|c|c|c|c|c|}
\hline \multirow{2}{*}{$\begin{array}{l}\text { Temperature, } \\
{ }^{\circ} \mathrm{C}\end{array}$} & \multicolumn{2}{|c|}{ Without corr. inhibitor } & \multicolumn{2}{|c|}{$50 \mathrm{ppm}$ of corr. inhibitor } \\
\hline & 35 & 70 & 35 & 70 \\
\hline$U_{\text {corr, }} \mathrm{mm}$ year ${ }^{-1}$ & 0,67 & 0,89 & 0,16 & 0,27 \\
\hline $\begin{array}{l}\text { Corr. inhibitor } \\
\text { efficiency,\% }\end{array}$ & - & - & 76 & 70 \\
\hline
\end{tabular}


Table 11. Comparison of the testing results obtained by EIS measurements in the carbon steel - oilfield brine system with the addition of $50 \mathrm{ppm}$ of corrosion inhibitor, tested with and without stirring

Tabelle 11. Vergleich der Testergebnisse der EIS - Messungen in Kohlenstoffstahl - Ölfeld Salzwasser System mit dem Zusatz von 50 ppm Korrosionsinhibitor, getestet mit und ohne Rühren

\begin{tabular}{lll}
\hline Stirring rate, RPM & 0 & 400 \\
\hline$R_{\mathrm{el}}$, Ohm & 4,60 & 8,94 \\
$R_{1}$, Ohm & 90 & 307 \\
$C_{1}, \mathrm{~F}$ & $4,16 \cdot 10^{-5}$ & $8,73 \cdot 10^{-5}$ \\
$R_{2}$, Ohm & 15 & 33 \\
$C_{2}, \mathrm{~F}$ & $55,9 \cdot 10^{-5}$ & $2,79 \cdot 10^{-5}$ \\
$R_{\mathrm{dl}}$, Ohm & 99 & 1050 \\
$C_{\mathrm{dl}}, \mathrm{F}$ & $66,0 \cdot 10^{-5}$ & $10,4 \cdot 10^{-5}$ \\
\hline
\end{tabular}

Table 12. Comparison of the testing results obtained by linear polarization measurements in the carbon steel - oilfield brine system without and with the addition of $50 \mathrm{ppm}$ of corrosion based corrosion inhibitor, tested with and without stirring

Tabelle 12. Vergleich der Testergebnisse durch lineare Polarisationsmessungen in Kohlenstoffstahl - Ölfeld Salzwasser System mit und ohne Zusatz von $50 \mathrm{ppm}$ Korrosion basierten Korrosionsinhibitor, getestet mit und ohne Rühren

Stirring rate, RPM Without corr. inhibitor $50 \mathrm{ppm}$ of corr. inhibitor

\begin{tabular}{lllll}
\cline { 2 - 3 } & 0 & 400 & 0 & 400 \\
\hline$u_{\text {corr }}$ mm year $^{-1}$ & 1,14 & 0,67 & 0,62 & 0,16 \\
\hline
\end{tabular}

\subsection{Influence of stirring of testing solution on the imidazoline based corrosion inhibitor efficiency}

EIS measurements were performed in order to investigate the effect of stirring on the efficiency of inhibitors. Carbon steel - oilfield brine system with $50 \mathrm{ppm}$ of imidazoline based corrosion inhibitor, without stirring, was tested first. All other testing conditions were the same as in the previously done testing. Results presented in the Table 11 shows that impedance resistance decreased and consequently corrosion rate was increased (corrosion inhibitor efficiency decreased).

Comparison of results obtained by linear polarization measurements in the carbon steel - oilfield brine system without and with addition of $50 \mathrm{ppm}$ of imidazoline based corrosion inhibitor, tested with and without stirring is presented in the Table 12. Corrosion rate was lower in the testing with stirring.

\section{Conclusions}

This work describes inhibition of carbon steel corrosion by imidazoline based corrosion inhibitor in carbon dioxide saturated oilfield brine solution. Obtained results by electrochemical measurements (electrochemical impedance spectroscopy, linear polarization and Tafel extrapolation method) lead to the following conclusions:

- The effectiveness of imidazoline based corrosion inhibitor increases until the concentration of $100 \mathrm{ppm}$ is reached, while further increase of the inhibitor concentration leads to the reduced effectiveness of inhibitor.

- 50 ppm of imidazoline based corrosion inhibitor is the optimal concentration for the addition into the carbon steel - carbon dioxide saturated oilfield brine system, under the conditions of $35^{\circ} \mathrm{C}$, atmospheric pressure and with stirring rate of $400 \mathrm{~min}^{-1}$.

- Increase of temperature results in increased corrosion rate in the tested system, regardless if imidazoline based corrosion inhibitor was added or not.

- Stirring of testing solution leads to a lower corrosion rate and consequently to increased effectiveness of imidazoline based corrosion inhibitor.

In the hottest period of the year in Croatia temperatures of oilfield brine solution in the pipelines are around $35^{\circ} \mathrm{C}$ (never $70^{\circ} \mathrm{C}$ ). Oilfield brines flow through these pipelines, therefore, tests with stirring of testing solution were more similar to oilfield conditions.

On the basis of the obtained results it can be concluded that oilfield pipelines (carbon steel - carbon dioxide saturated oilfield brine) can be successfully protected with the addition of $50 \mathrm{ppm}$ (optimal concentration) of imidazoline based corrosion inhibitor under the conditions of $35^{\circ} \mathrm{C}$, atmospheric pressure and with stirring rate of $400 \mathrm{~min}^{-1}$.

\section{References}

[1] D. A. Lopez, W. H. Schreiner, S. R. de Sanches, S. N. Simison, Appl. Surf. Sci. 2003, 207, 69.

[2] V. S. Sastri, Corrosion Inhibitors: Principles and Applications, J. Wiley \& Sons, New York, Reprinted 2001.

[3] P. S. Rothman, W. T. Young In: R. Baboian, Editors, Corrosion Tests and Standards: Application and Interpretation, $2^{\text {nd }}$ Ed., ASTM International, West Conshohocken, 2005, 696.

[4] L. Gaverick, Corrosion in the Petrochemical Industry, ASM International, $3^{\text {rd }}$ Ed., Materials Park, 1999.

[5] R. S. Treseder, R. N. Tuttle, Corrosion Control in Oil and Gas Production, Corupdate Inc., Houston, 1998.

[6] ASTM G170-06, Standard Guide for Evaluating and Qualifying Oilfield and Refinery Corrosion Inhibitors in Laboratory, ASTM International, West Conshohocken, 2001.

[7] S. Papavinasam, R. W. Revie, M. Attard, A. Demoz, K. Michaelian, Corrosion 2003, 59, 897.

[8] H. G. Byars, Corrosion Control in Petroleum Production, $2^{\text {nd }}$ Ed., NACE, TPC Publ. 5, Houston 1999.

[9] A. G. Ostroff, Introduction to Oilfield Water Technology, $2^{\text {nd }}$ Ed., NACE, Houston, 1979.

[10] R. Vasquez, L. Hazan, J. Uruchurtu, J. M. Malo, J. Genesca, Afinidad 2003, 60, 136.

[11] A. M. S. Abdennabi, A. I. Abdulhadi, S. Abu-Orabi, AntiCorros. Methods Mater. 1998, 45, 103.

[12] Y. A. Sazonov, T. A. Marakayev, G. K. Kortmakher, V. K. Lopina, R. M. Akhmetzyanova, Neftyanoe Khozyaistvo 1995 , 8,32 .

[13] M. A. Migahed, A. M. Al-Sabagh, Chem. Eng. Commun. 2009, 196, 1054.

[14] W. Wang, M. L. Free, D. Horsup, Metall. Mater. Trans. B. $2005,36,335$. 
[15] A. J. Son, presented at NACE International Corrosion Conference \& Expo 2007, Paper no. 07618, 2007.

[16] T. M. McCullough, US Patent 5104 578, 1992.

[17] J. Maddox, US Patent 3629 104, 1971.

[18] J. Maddox, US Patent 3758 493, 1973.

[19] E. Stupnišek-Lisac, A.L. Božić, I. Cafuk, Corrosion 1998, 54, 713.

[20] D. Doležal, T. Bolanča, S. Cerjan Stefanović, Materialwiss. Werkstofftech. 2011, 42, 229.

[21] D. Doležal, Ph.D.Thesis, University of Zagreb, Croatia, 2011.

[22] D. M. Ortega-Toledo, J. G. Gonzalez-Rodriguez, M. Casales, M. A. Neri-Florez, A. Martinez-Villafane, Mater. Chem. Phys. 2010, 122, 485.

[23] L. D. Paolinelli, T. Pérez, S. N. Simison, Mater. Chem. Phys. 2011, 126, 938.

[24] P. C. Okafor, C. B. Liu, X. Liu, Y. G. Zheng, J. Appl. Electrochem. 2009, 39, 2535.

[25] P. C. Okafor, X. Liu, Y. G. Zheng, Corros. Sci. 2009, 51, 761.

[26] W. Villamizar, M. Casales, L. Martinez, J. G. Chacon-Naca, J. G. Gonzalez-Rodriguez, J. Solid State Electrochem. 2008, 12, 193.

[27] F. G. Liu, M. Du, J. Zhang, M. Qiu, Acta Phys.-Chim. Sin. 2008, 24, 138 .
[28] L. D. Paolinelli, T. Perez, S. N. Simison, Corros. Sci. 2008, $50,2456$.

[29] ASTM G3-89(2010), Standard Practice for Conventions Applicable to Electrochemical Measurements in Corrosion Testing, ASTM International, West Conshohocken, 2010.

[30] ASTM G5-94(211)e1, Standard Reference Test Method for Making Potentiostatic and Potentiodynamic Anodic Polarization Measurements, ASTM International, West Conshohocken, 2011.

[31] ASTM G59-97(2009), Standard Test Method for Conducting Potentiodynamic Polarization Resistance Measurements, ASTM International, West Conshohocken, 2009.

[32] ASTM G102-89(2010), Standard Practice for Calculation of Corrosion Rates and Related Information from Electrochemical Measurements, ASTM International, West Conshohocken, 2010.

[33] ASTM G106-89(2010), Standard Practice for Verification of Algorithm and Equipment for Electrochemical Impedance Measurements, ASTM International, West Conshohocken, 2010.

[34] ASTM NACE/ASTM G193-12a, Standard Terminology and Acronyms Relating to Corrosion, ASTM International, West Conshohocken, 2012.

Received in final form: September $14^{\text {th }} 2012$

T 62 